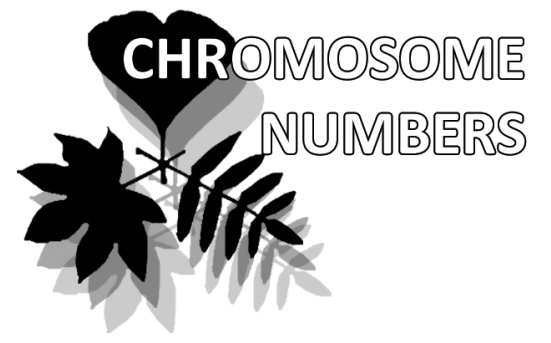

Nina S. Probatova ${ }^{1 *}$, Vitaly P. Seledets ${ }^{2} \&$ Vyacheslav Yu. Barkalov $^{1}$

\section{Chromosome numbers in some species of Poaceae from Russia}

Nina S. Probatova ${ }^{1 *}$

e-mail: probatova@ibss.dvo.ru

Vitaly P. Seledets ${ }^{2}$

e-mail: probatova@ibss.dvo.ru

Vyacheslav Yu. Barkalov ${ }^{1}$

e-mail: barkalov@ibss.dvo.ru

${ }^{1}$ Institute of Biology \& Soil Science FEB RAS, Vladivostok, Russia

${ }^{2}$ Pacific Institute of Geography FEB RAS, Vladivostok, Russia

* author for correspondence

Manuscript received: 20.03 .2015

Review completed: 29.03.2015

Accepted for publication: 01.04.2015

Published online: 20.04.2015

\begin{abstract}
A B S T R A C T
Chromosome numbers (CN) for 35 species and one hybrid in Poaceae from 9 genera: Beckmannia, Brachypodium, Bromopsis, Catabrosa, Elymus, Elytrigia, Festuca, Milium, Poa, from Russia are presented. For Bromopsis austrosibirica Peschkova, Deschampsia baicalensis Tzvelev, D. submutica (Trautv.) O.D. Nikif., Festuca chionobia T.V. Egorova et Sipliv., F. dahurica (St.-Yves) V.I. Krecz. et Bobrov, F. kolesnikovii Tzvelev, F. vylzaniae (E. Alexeev) Tzvelev, Poa khokhrjakovii Prob. and P. krasnoborovii Stepanov the $\mathrm{CNs}$ were revealed for the first time. The new CNs were obtained for Bromopsis heterophylla (Klokov) Holub, Deschampsia obensis Roshev., Elytrigia trichophora (Link) Nevski. Some species were studied first time: Elymus kamoji (Ohwi) S.L. Chen and Catabrosa minor (Bab.) Tzvelev - in Russia, P. glauca Vahl - in Amurskaya Oblast', Festuca jacutica Drobow - in Khabarovskii Krai, Poa angustifolia L. - in the North Koryakia, Milium effusum L. and Deschampsia komarovii V.N. Vassil. - in Kamchatka Peninsula. From the Commander Islands the hybrid Poa alpigena (Blytt) Lindm. $\times$ P. arctica $\mathrm{R}$. Br. was studied. Besides, in the "tuft form" of Festuca rubra L., which is distributed along seacoast and islands of the Primorskii Krai, the CN was firstly revealed. F. chionobia obviously is the first pseudoviviparous species with the diploid CN $(2 \mathrm{n}=14)$.

K e y w o r d s : chromosome numbers, vascular plants, Poaceae, flora, Russia
\end{abstract}

\section{P E 3 Ю M E}

Пробатова Н.С., Селедец В.П., Баркалов В.Ю. Числа хромосом некоторых видов змаков (Роасеае) России

Приводятся числа хромосом (2n) Аля 35 видов и одного гибрида зАаков из родов Beckmannia, Brachypodium, Bromopsis, Catabrosa, Elymus, Elytrigia, Festuca, Milium, Роа во флоре России. Впервые исследованы в кариологическом отношении Bromopsis austrosibirica Peschkova, Deschampsia baicalensis Tzvelev, D. submutica (Trautv.) O.D. Nikif., Festuca chionobia T.V. Egorova et Sipliv., F. daburica (St.-Yves) V.I. Krecz. et Bobrov, F. kolesnikovii Tzvelev, F. vylzaniae (E. Alexeev) Tzvelev, Poa khokhrjakovii Prob., P. krasnoborovii Stepanov. Новые (не известные ранее) числа хромосом установлены у Bromopsis heterophylla (Klokov) Holub, Deschampsia obensis Roshev., Elytrigia trichophora (Link) Nevski. Elymus kamoji (Ohwi) S.L. Chen и Catabrosa minor (Bab.) Tzvelev исследованы впервые Аля России, Poa glauca Vahl - впервые Аля Амурской обл., Festuca jacutica Drobow - в Хабаровском крае, Poa angustifolia L. - в Северной Корякии, Milium effusum L. и Deschampsia komarovii V.N. Vassil. впервые исследованы на Камчатке. На Командорских островах изучен гибрид Poa alpigena (Blytt) Lindm. $\times$ P. arctica R. Br. Впервые установлено число хромосом у дернистой формы Festuca rubra L., которая встречается на морском побережье и островах в Приморском крае. Впервые выявлен псевдовивипарный таксон освяницы с Аиплоилным числом хромосом - Festuca chionobia $(2 \mathrm{n}=14)$.

К $\boldsymbol{\Lambda}$ юче вы е скова: числа хромосом, сосудистые растения, злаки, Poaceae, флора, Россия
Here we present results of chromosome number (CN) study of 35 Poaceae species from Russia, mainly from East Siberia and the Russian Far East (RFE), as well as from European Arctic, North Caucasus and Crimea (Fig. 1). Chromosome countings in some species were made by E.G. Rudyka (indicated by ER), on squashed preparations of root tips fixed with Carnoy's solution. We also include here some previous $\mathrm{CN}$ countings of A.P. Sokolovskaya (indicated by AS). The root tips were taken from living plants, or from seedlings obtained through herbarium specimens, which were collected in the field. Preparations were stained with iron hematoxylin. Voucher specimens are preserved in the Herbarium VLA, Vladivostok (some - in LE,
St. Petersburg). First $\mathrm{CN}$ data are indicated by asterisk $\left({ }^{*}\right)$. The number of the dot on the map follows the number of voucher specimen. Brief information on the affinity and distribution of the species studied is presented.

\section{Beckmannia borealis (Tzvelev) Prob., 2n = 14 (ER)}

Russia, the Far East, Kamchatka Peninsula, Bystrinskii Raion, Anavgai village, water-logged ground at the rivulet, 322 m alt., 9 Aug 2013, coll. V.V. Buryi 12597: 10. Endemic of Russia. This species is distributed in the north and central parts of European Russia, in Altai and Yakutia, and it is a rare species in the Russian Far East (RFE), where it occurs 


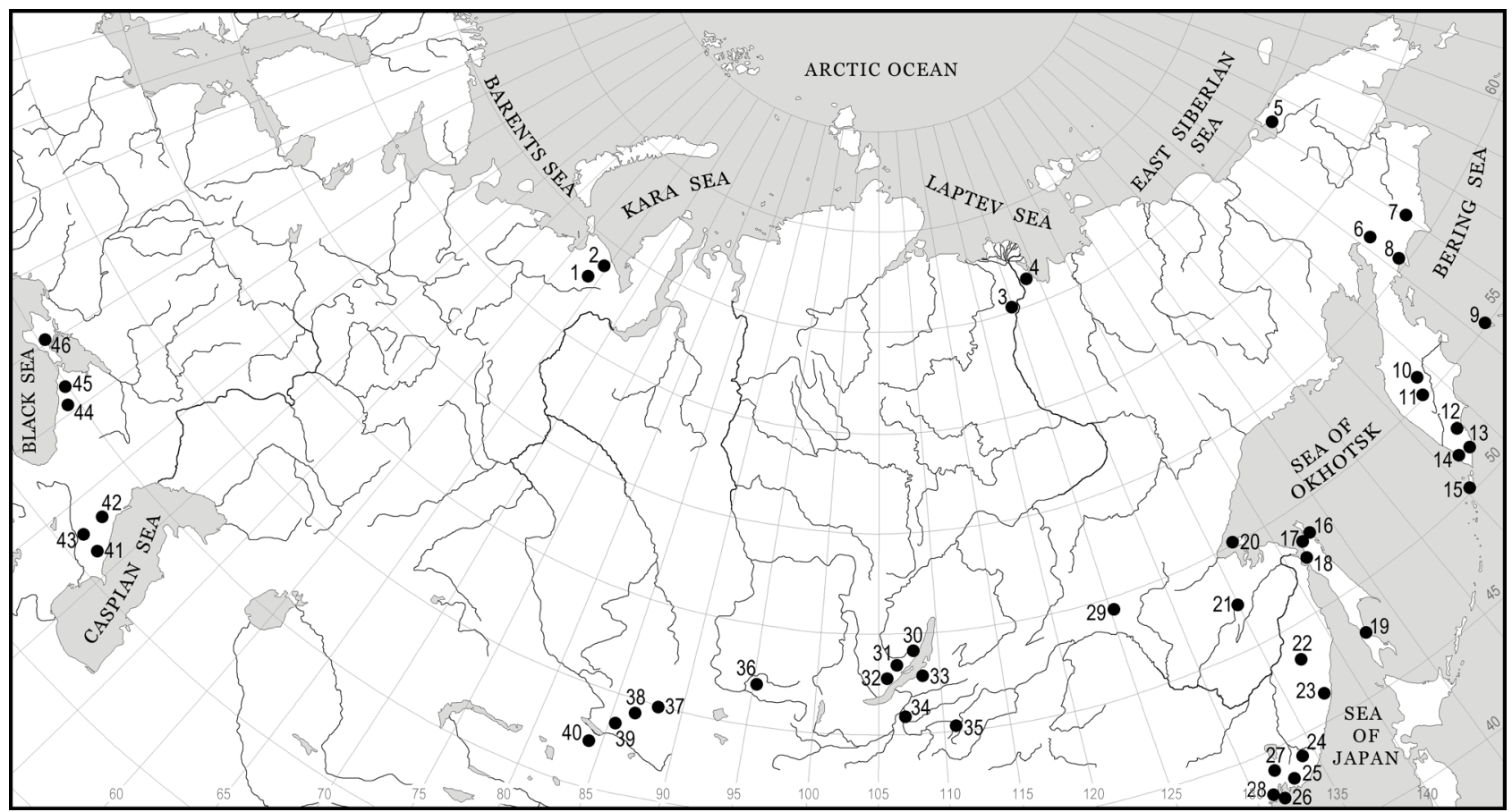

Figure 1 Study area. Dots with numbers from 1 to 44 are the sampling plot locations

in wet meadows of riversides in Kamchatka (mainly central) and Okhotia (near Magadan). This species is probably arised from hybridization of B. syzigachne (Steud.) Fern. $\times$ B. eruciformis (L.) Host, but now the last species is absent in the RFE. The RFE populations of B. borealis possibly are relict. The $\mathrm{CN}$ of $B$. borealis was studied in Altai, Yakutia and Kamchatka (Probatova \& Sokolovskaya 1980, 1984; Probatova \& Seledets 2008). All the species of the small genus Beck.mannia are diploids. $2 \mathrm{n}=2 \mathrm{x}$.

Brachypodium spryginii (Tzvelev) Tzvelev (B. sylvaticum (Huds.) P. Beauv. subsp. spryginii Tzvelev), $\mathbf{2 n}=\mathbf{1 8}$ (ER)

Russia, North Caucasus, Krasnodarskii Krai, Abinskii Raion, $18 \mathrm{~km} \mathrm{~S}$ of Abinsk town, near Shapsugskaya village, the riverside forest along the Abin River (the Kuban' River basin), 1 Sep 2009, coll. N.S. Probatova \& V.P. Seledets 11652: 44. This species was described from Crimea and it is distributed also in the North Caucasus (west part, including the Kuban' River basin and the coast of the Black Sea). It is related to B. sylvaticum (Huds.) P. Beauv., where $2 \mathrm{n}=18$ is also known by multiple authors. We present here the second CN counting for B. spryginii (the first was in Probatova, Kazanovsky, Rudyka et al. 2012). 2n $=2 \mathrm{x}$. The $\mathrm{CN}$ of species related to B. sylvaticum is constant $(\mathrm{x}=9)$, however Brachypodium is polybasic genus.

Bromopsis australis (Zherebina) Tzvelev et Prob., 2n = 28 (AS)

Russia, East Siberia, Republic of Buryatia, outskirts of Ulan-Ude city, meadow with steppe vegetation near airport, 12 Sep 1989, coll. N.S. Probatova \& V.P. Seledets 6934: 34. Earlier the specimen № 6934 was misidentified as «Bromopsis inermis" by Probatova, Sokolovskaya \& Rudyka (1991). This steppe species was described from the south of Ural and was revealed in European Russia, North Caucasus, West and East (w) Siberia. It can be found in the RFE as well (as adventive), just like its closely relative B. inermis (Leyss.) Holub (which is considered as forest species everywhere, but alien in the RFE). Both species have variable ploidy: $2 \mathrm{n}=$ 28, 42, 56 - many CN counts for B. inermis, but less - for B. australis: $2 \mathrm{n}=28,56$ (Tzvelev \& Probatova $2010 \mathrm{a}$; Probatova et al. 2010). In the past these forest and steppe species probably were more isolated, but now B. inermis, which is younger and more active than $B$. australis, owing to human impact, widely extended its area of distribution to the south and they easily hybridize (Tzvelev \& Probatova 2010 a). 2n $=4 \mathrm{x}, 6 \mathrm{x}$.

\section{${ }^{*}$ Bromopsis austrosibirica Peschkova, 2n = 28 (AS)}

Russia, East Siberia, Republic Sakha-Yakutia, Bulunskii Raion, left riverside of the Lena River, $30 \mathrm{~km}$ above Kiussiur settlement, near the mouth of the Tegeliakh River, steep slope, 4 Aug 1973, coll. N.S. Probatova \& V.P. Seledets 3771: 3. Occurs on forest edges and clearings in the river valleys. The Altai - East Siberian endemic species. It belongs to the group of B. aggr. pumpelliana (Scribn.) Holub. This is the first CN counting for B. austrosibirica. Most likely it has variable ploidy, like the species of this affinity. Further studies are needed. $2 \mathrm{n}=4 \mathrm{x}$.

Bromopsis benekenii (Lange) Holub, 2n = 28 (AS)

Russia, North Caucasus, Republic of Daghestan, Buinakskii Raion, $16 \mathrm{~km}$ W of Buinaksk town, near Manas-aul, $960 \mathrm{~m}$ alt., the foot of Gimrinskii mountain ridge, the tourist centre "Termenlik", beech forest, 18 Jun 1979, coll. N.S. Probatova 5410: 42. This forest species is distributed from Europe and Caucasus to West Siberia. The same CN 2n = 28 was earlier revealed from Azerbaidzhan (Sokolovskaya \& Probatova 1979 - as B. ramosa ssp. benekenii), but the report of $2 \mathrm{n}=42$ also exists in the literature (see in Agapova et al. 1993). $2 \mathrm{n}=4 \mathrm{x}$.

\section{Bromopsis heterophylla (Klokov) Holub, ${ }^{*} \mathbf{2 n}=56$ (AS)}

Russia, Republic of Crimea, Ai-Petrinskaya yaila, on the slope, 13 Aug 1974, coll. V.V. Fedyaeva 3958: 46. The 
steppe species, distributed in the south-east of Europe, but described from Crimea. Probably it shows variable ploidy: before the newly revealed $\mathrm{CN} 2 \mathrm{n}=56$, the diploid $\mathrm{CN} 2 \mathrm{n}$ $=14$ was known from Crimea (see Prokudin et al. 1977 as "B. cappadocica"); however these cytotypes may belong to different taxa. $2 \mathrm{n}=8 \mathrm{x}$.

\section{Bromopsis variegata (M. Bieb.) Holub, 2n = 14 (AS)}

Russia, North Caucasus, Republic of Daghestan, Gunibskii Raion, near Verkhnii Gunib village, $1800 \mathrm{~m}$ alt., sandy-pebbly bank of the Gunibka River, 26 Jun 1979, coll. N.S. Probatova 5420: 41. The species is distributed in the Russian Caucasus, in high mountains. The CN 2n = 14 was known from Kabardino-Balkaria Republic (Sokolovskaya \& Probatova 1979). $2 \mathrm{n}=2 \mathrm{x}$.

Catabrosa minor (Bab.) Tzvelev (C. aquatica var. minor Bab.), 2n = 20 (AS)

Russia, European Arctic, Komi Republic, in vicinity of Vorkuta city, the farm (sovkhoz) "Tsentral'nyi", weedy place, 17 Jul 1967, coll. N.N. Tzvelev 63 (LE); A.P. Sokolovskaya 124: 2. This specimen was misidentified as "Catabrosa aquatica s. str." (Sokolovskaya 1970; Sokolovskaya \& Probatova 1975). C. minor was collected by Tzvelev in the same expedition with Sokolovskaya, and she counted the $\mathrm{CN}$ on this specimen (but with her number 124). The correct name of this plant was determined much later (Tzvelev 2013). C. minor occurs near seacoasts in European Arctic, but in Komi Republic, near Vorkuta, it is adventive. The related widespread species C. aquatica (L.) P. Beauv. does not occur in the Arctic. $2 \mathrm{n}=4 \mathrm{x}$.

\section{* Deschampsia baicalensis Tzvelev, 2n = 26 (ER)}

Russia, East Siberia, Irkutskaya Oblast', Ol'khonskii Raion, W lakeside of Baikal Lake, the Khokhe-Nokhoitui Cape, $496 \mathrm{~m}$ alt., on bank of the swampy lakelet behind the lakeside barrage, 28 Jul 2005, coll. S.G. Kazanovsky 11600 : 30; Russia, East Siberia, Irkutskaya Oblast', Ol'khonskii Raion, near Chernorud settlement, the Kuchulga River, $464 \mathrm{~m}$ alt., former river-bed, the lowland sedge marsh, 1 Aug 2004, coll. S.G. Kazanovsky 11321: 31. Sandy and muddy banks of river deltas. East Siberia (the Baikal Lake). Endemic. Probably the species was originated from hybridization between D. turczaninowii (Litv.) Roshev. and D. sukatschewii (Popl.) Roshev. This is the first chromosome count for the species. $2 \mathrm{n}=2 \mathrm{x}$.

\section{Deschampsia glauca Hartm., 2n = c. 26 (AS)}

Russia, East Siberia, Republic of Sakha-Yakutia, lower course of the Lena River, in vicinity of the Tiksi Bay, on stony plots of riverside of a small river, 1 Aug 1948, coll. A.P. Sokolovskaya 129: 4. Earlier this specimen was misidentified as " $D$. caespitosa subsp. borealis" by Sokolovskaya \& Probatova (1975). In tundras, meadows, on pebbles and stony slopes, by the streams. East Europe (from Arctic to Ural - north and middle), West Siberia (Arctic, Ob' River - as adventive), East Siberia (Arctic, Putorana Mts., Lena and Kolyma - north), RFE (Arctic, Anadyr', Penzhina); Europe (Scandinavia), North America (Alaska). (Tzvelev \& Probatova 2012). $-2 \mathrm{n}=26,48,52$ (Zhukova \& Tikhonova
1973; Zhukova \& Petrovsky 1976; Yurtzev \& Zhukova 1978; Petrovsky \& Zhukova 1981: Chukotka, Wrangel Isl.). In the RFE this species becomes rare, the $\mathrm{CN}$ reports for southern parts of RFE probably belong to $D$. paramushirensis. $2 \mathrm{n}=2 \mathrm{x}, 4 \mathrm{x}$.

\section{Deschampsia komarovii V.N. Vassil., 2n = 26 (ER)}

Russia, the Far East, Kamchatskii Krai, Kamchatka Peninsula, Bystrinskii Raion, the bottom of temporary lake, 884 m alt., 19 Aug 2013, V.V. Buryi 12598: 11; Russia, Far East, Kamchatskii Krai, Kamchatka Peninsula, Elizovskii Raion, Mutnovskii Volcano, poorly matted slope, above the geysers plot "Dachnyi", 20 Aug 2004, coll. A.N. Berkutenko \& M.A. Polezhaeva 9670: 13. Riverside and coastal meadows, sands and pebbles. RFE (Arctic, Kamchatka, Okhotia). Endemic. 2n = 26, 38, 42 (Zhukova et al. 1973; Yurtzev \& Zhukova 1978: Chukotka - east, Wrangel Isl.). 2n $=2 \mathrm{x}$ and aneuploids.

\section{Deschampsia macrothyrsa (Tatew. et Ohwi) Kawano, 2n $=\mathbf{2 6}(\mathrm{ER})$}

Russia, the Far East, Sakhalin (north), Ekhabi Bay, SE of Vostochnyi settlement, on the bank of a brackish lake, 3 Aug 2001, coll. V.Yu. Barkalov 8606: 16. Coastal boggy meadows, swamps. RFE: Sakhalin, the Kurils (south), reported from Okhotia (south); East Asia (Hokkaido). Described from Hokkaido. 2n = 26 (Probatova 1984; Probatova et al. 2009: Sakhalin). $2 \mathrm{n}=2 \mathrm{x}$.

\section{Deschampsia obensis Roshev., * $2 \mathrm{n}=\mathbf{2 6}$ (AS)}

Russia, Komi Republic, Intinskii Raion, the farm (sovkhoz) "Gornyak", the farm Yun'-Yaga, the Yun'-Yaga River, along sandbanks, 12 Jul 1967, coll. A.P. Sokolovskaya 77: 1. Earlier this specimen was misidentified as " $D$. caespitosa subsp. orientalis" (Sokolovskaya \& Probatova 1975). Sandy and pebble banks of river valleys in lower courses, poorly fixed and mobile sands of rivers and near seacoast. East Europe (Arctic, Kola Peninsula, Pechora River, Ural - north); West Siberia (Arctic and lower course of the Ob' River); East Siberia (Arctic); RFE (Arctic - west). Endemic. $2 \mathrm{n}=>42,>44,52$ (Zhukova \& Petrovsky 1975; Zhukova \& Petrovsky 1980: Chukotka). 2n $=2 \mathrm{x}, 4 \mathrm{x}$.

\section{Deschampsia pamirica Roshev., 2n = 26 (AS)}

Russia, West Siberia, Altai, Chuyskaya steppe, KoshAgach, 1835 m alt., along the riverside, 25 Jul 1937, coll. A.P. Sokolovskaya \& O.S. Strelkova 26: 38; Russia, West Siberia, Altai, the Kuraiskii mountain ridge, Tabozhek canyon, $2300 \mathrm{~m}$ alt., on placer deposits, 30 Jul 1937, coll. A.P. Sokolovskaya \& O.S. Strelkova 73: 37; Russia, West Siberia, Altai, the Chegan-Uzun River, $2000 \mathrm{~m}$ alt., pebbles on the slope, 5 Aug 1937, coll. A.P. Sokolovskaya \& O.S. Strelkova 125: 39; Russia, West Siberia, Altai, Katunskie Belki, the Kazinikha Pass, 2400 m alt., 20 Aug 1937, coll. A.P. Sokolovskaya \& O.S. Strelkova 165: 40. Earlier all these specimens were misidentified as " $D$. caespitosa subsp. koelerioides" in Sokolovskaya \& Probatova (1975). Saline meadows, sands and pebbles; in the middle and upper mountain belts. West Siberia (Altai), East Siberia (West Sayan); Middle and Central Asia. 2n $=2 \mathrm{x}$. 
Deschampsia paramushirensis Honda (D. cespitosa (L.) P. Beauv. subsp. orientalis Hultén), 2n = 26 (AS, ER)

Russia, the Far East, Sakhalin (north), near the former settlement Muz'ma, N of Pomr' Bay, 10 Aug 2001, coll. V.Yu. Barkalov 8613: 18; Russia, the Far East, the North Kurils, Paramushir Island, outskirts of Severo-Kuril'sk settlement, on pasture, 20 Aug 1971, coll. N.S. Probatova 3351: 16; Russia, the Far East, Khabarovskii Krai, Tuguro-Chumikanskii Raion, the Shantarskie Islands, Feklistova Island, N coast, Lissya Bay, Lissje Lake, at the rivulet, 20 Aug 2010, coll. V.V. Bogatov 12326: 20; Russia, the Far East, Sakhalin (north), outskirts of Moskalvo settlement, by the lake, Aug 2001, coll. V.Yu. Barkalov 8601: 17. Earlier the specimen № 3351 was misidentified as "D. cespitosa s. str." (Sokolovskaya \& Probatova 1975) and the specimen № 12326 as "D. glauca" (Probatova et al. 2014). Riverside and seaside meadows, sands and pebbles. RFE (Anadyr' River basin, North Koryakia, Kamchatka, Okhotia, Sakhalin - north, North Kurils); East Asia (Hokkaido). Some reports of various CNs for D. paramushirensis (also under other names, e.g., its synonym D. cespitosa subsp. orientalis - see in Agapova et al. 1993) hardly belong to this species, which obviously occurs in oceanic (coastal) regions of NE Asia. The revision of the whole material studied is needed. $2 \mathrm{n}=2 \mathrm{x}$.

*Deschampsia submutica (Trautv.) O.D. Nikif., 2n = 26 (P.G. Zhukova - LE, VLA)

Russia, Far East, Chukotskii natsionalnyi okrug, E coast of the Chaunskaya Guba [Gulf], Apapelkhino settlement, 2 Sep 1965, V.V. Petrovsky \& P.G. Zhukova 65-436: 5. Sands and pebbles on riversides, wet meadows, among shrubs. East Europe (Arctic, Ural - north), West Siberia (Arctic, Ob' River basin - north), East Siberia (Arctic - south, Yenissei north, Lena and Kolyma), RFE (Chukotka - west). Endemic. $2 \mathrm{n}=2 \mathrm{x}$.

Deschampsia sukatschewii (Popl.) Roshev., 2n = 26 (AS, ER)

Russia, East Siberia, Irkutskaya Oblast', Irkutskii Raion, Baikal Lake, the mouth of the Bol'shaya Goloustnaya River, along the lakeside barrage at the lagoon lake, 4 Sep 2003, coll. V.V. Chepinoga \& al. 9098: 32; Russia, the Far East, North Koryakia, Olyutorskii Raion, $2.5 \mathrm{~km} \mathrm{~S}$ of Khailino settlement, on pebbles of a rivulet, 16 Aug 1970, coll. N.S. Probatova \& V.P. Seledets 2655: 7; Russia, the Far East, Sakhalin, Makarovskii Raion, near the railway station Pugachevo, on the railroad embankment, abundant, $15 \mathrm{Sep}$ 1982, coll. N.S. Probatova, V.P. Seledets \& al. 6270: 19. The specimen № 2655 earlier was misidentified as “ $D$. caespitosa subsp. orientalis" in Sokolovskaya \& Probatova (1975). Sands and pebbles on riversides, forest clearings, forest edges; up to the middle mountain belt. East Europe (Arctic, Pechora and Mezen' rivers); West Siberia (Arctic, the Ob' River, Altai), East Siberia, RFE; Asia (Central - north) and E (northwest). $2 \mathrm{n}=26,28,42,42+1 \mathrm{~B}, 52$ (see Agapova et al. 1993; Zhukova et al. 2009; Chepinoga et al. 2010; Probatova et al. 2014). Many of the multiple reports with various $\mathrm{CN}$ for D. sukatschewii (including under other names, e.g., D. cespitosa subsp. orientalis) hardly belong to this continental forest species, which occurs for certain in East Siberia and in the south of continental Far East (the Amur River basin). The revision of the whole material studied as to $\mathrm{CNs}$ is needed. $2 \mathrm{n}=2 \mathrm{x}, 4 \mathrm{x}$.

Elymus kamoji (Ohwi) S.L. Chen (Agropyron tsukushiense (Honda) Ohwi var. transiens (Hack.) Ohwi), 2n = 42 (ER)

Russia, the Far East, Primorskii Krai, Khassanskii Raion, Slavyanka town, a meadow near the sea front, 19 Aug 2012, coll. A.V. Agafonov 12719: 28. East Asian species, described from the North-East China. It was revealed recently in the RFE (Primorskii Krai, Khassanskii Raion), firstly - from Ryazanovka settlement (Tzvelev \& Probatova $2010 \mathrm{~b}$ ). This is the second record of the species for Russia. The hexaploid CN $2 n=42$ is typical for two closely related East Asian species - E. kamoji (Nishikawa 2008) and E. tsukushiensis Honda, but uncommon in the section Goulardia. In the RFE E. tsukushiensis was found in Kunashir Isl., South Kurils ( $2 \mathrm{n}=42$ - Probatova et al. 2000). $2 \mathrm{n}=6 \mathrm{x}$.

\section{Elytrigia gracillima (Nevski) Nevski, 2n = 28 (AS)}

Russia, North Caucasus, Republic of Daghestan, Gunibskii Raion, near Verkhnii Gunib village, Khotochinskii mountain ridge, ca. $2000 \mathrm{~m}$ alt., on the rocks, 26 Jun 1979, coll. N.S. Probatova 5424: 43. On limestone rocks and stony slopes, in lower and middle mountain belts. Caucasian species; described from Daghestan. This is the second CN counting from Russia, also from Daghestan $(2 \mathrm{n}=28$ - Probatova \& Sokolovskaya 1978). $2 \mathrm{n}=4 \mathrm{x}$.

\section{Elytrigia repens $(\mathrm{L}$.$) Nevski, 2n = 42$ (ER)}

Russia, the Far East, Primorskii Krai, Mikhailovskii Raion, outskirts of Novoshakhtinskii town, as a weed in vegetable garden, 27 Jul 2004, coll. V.T. Lapenko 11676: 27. Meadows, forest clearings, on sands and pebbles, often as a weed. Holarctic. Everywhere in Russia, but alien in the RFE. Multiple CN data published, almost all of them $-2 n$ $=42.2 \mathrm{n}=6 \mathrm{x}$.

\section{Elytrigia stipifolia (Czern. ex Nevski) Nevski, 2n = 28 (AS, ER)}

Russia, North Caucasus, Republic of Daghestan, Gunibskii Raion, near Kharti-Kuni village, on the slope with Pinus kochiana, at the pass, 16 Jul 1975, coll. N.S. Probatova \& V.P. Seledets 4058: 39. Earlier this specimen was misidentified as "Elytrigia tauri subsp. pertenuis" in Probatova \& Sokolovskaya (1978). On exposed chalk and limestone, in steppes, up to the lower mountain belt. East Europe, Caucasus. $2 \mathrm{n}=28$ (see Prokudin et al. 1977). $2 \mathrm{n}=4 \mathrm{x}$.

\section{Elytrigia trichophora (Link) Nevski, * 2 n $=\mathbf{2 8}(\mathrm{ER})$}

Russia, North Caucasus, Krasnodarskii Krai, Novorossiyskii Raion, in vicinity of Raevskaya settlement, Volchye Vorota Pass, rubbly marl placer, 3 Sep 2009, coll. N.S. Probatova \& V.P. Seledets 11612: 45. In steppes, stony slopes, among shrubs, up to lower mountain belt. East Europe, Caucasus, Central Asia. 2n = 42 (see Prokudin et al. 1977; Sokolovskaya \& Probatova 1978). New cytotype for the species. $2 \mathrm{n}=4 \mathrm{x}, 6 \mathrm{x}$.

${ }^{*}$ Festuca chionobia T.V. Egorova et Sipliv. (F. auriculata subsp. chionobia (T.V. Egorova et Sipliv.) Tzvelev), 2n = 14 (ER)

Russia, the Far East, Khabarovskii Krai, Nanaiskii Raion, Sikhote-Alin' mountain range, the Tardoki-Yani Mt., upper 
course of Sukhaya Pad' stream (the Anjui River basin), 1900 $\mathrm{m}$ alt., alpine belt, stony dwarfshrub-mossy tundra, 29 Aug 2012, coll. V.Yu. Barkalov 12189: 22. Mountain tundras and meadows. Baikal Siberia, RFE. Endemic. Described from the Baikal'skii mountain ridge. In RFE it occurs mainly in high altitudes of Sikhote-Alin' and also in the mountains of the Upper Amur River basin. The species belongs to F. aggr. auriculata Drobow. For F. auriculata there are many $\mathrm{CN}$ reports of $2 \mathrm{n}=14$ only, from Chukotka, Wrangel Isl. and East Siberia (see Agapova et al., 1993). Another related species is F. mollissima V.I. Krecz. et Bobrov, also with 2n = 14 (many CN counts from Primorskii Krai; see in Probatova, 2014). F. chionobia is a pseudoviviparous species. (Fig. 2). This is the first $\mathrm{CN}$ counting for F. chionobia. Obviously it is the first pseudoviviparous species with diploid CN 2n $=14$. Other festucoid grasses with pseudoviviparity (Deschampsia, Festuca, Poa) are polyploids and aneuploids: see the review of Sarapul'tsev (2001).

* Festuca daburica (St.-Yves) V.I. Krecz. et Bobrov, 2n = 14 (ER)

Russia, East Siberia, Republic of Buryatia, Mukhorshibirskii Raion, near Olon-Sheber Lake, on sands, 3 Jul 2010, coll. A.A. Gnutikov \& Yu.A. Gnutikova 12259: 35. Mostly Chinese species; occurs on rocks and steppes. In Russia it is distributed in the south of Transbaikalia. Its $\mathrm{CN}$ was revealed for the first time. $2 \mathrm{n}=2 \mathrm{x}$.

\section{Festuca jacutica Drobow, 2n = 14 (ER)}

Russia, the Far East, Khabarovskii Krai, Poliny Ossipenko Raion, the valley of the Nylan River (left tributary of the Amgun' River), middle course, stony outcrops with limestone "Mramornye skaly" on the right riverside, fissures in the rocks, 25 Jul 2012, coll. M.V. Kriukova \& L.A. Antonova 12680: 21. In light forests, among shrubs, on stony slopes and rocks. East Siberia, RFE (Kolyma, Okhotia, the Amur River basin); Northeast China. Described from Yakutia. 2n = 14 (Yurtzev \& Zhukova 1982; Probatova \& Sokolovskaya 1984). First $\mathrm{CN}$ data from Khabarovskii Krai. 2n = 2x.

\section{${ }^{*}$ Festuca kolesnikovii Tzvelev, 2n = 14 (ER)}

Russia, the Far East, Primorskii Krai, Terneiskii Raion, Sikhote-Alinskii biosphere reserve, locality Blagodatnoe, marine terrace, dry meadow with steppe features, 25 Jun 2003, coll. I.A. Nesterova 9023: 23; Russia, the Far East, Primorskii Krai, Peter the Great Bay, Lissyi Island (opposite Nakhodka city), 11 Sep 2002, coll. V.A. Nechaev 8901: 25. On costal rocks, stony slopes and pebbles. RFE: Primorskii Krai (east macroslope of Sikhote-Alin' mountain ridge). Endemic. Most probably this species has hybrid origin: F. aggr. ovina L. $\times$ F. aggr. auriculata Drobow. First $C N$ data for the species. $2 \mathrm{n}=2 \mathrm{x}$.

\section{Festuca mollissima V.I. Krecz. et Bobrov, 2n = 14 (ER)}

Russia, the Far East, Primorskii Krai, Partizanskii Raion, Alexeevskii mountain ridge, Olkhovaya Mt., on the spots of fine-grain soil, $1600 \mathrm{~m}$ alt., 10 Sep 2010, coll. V. Yu. Barkalov 11667: 24. On stony slopes and rocks, sometimes on coastal sands and pebbles, up to the middle mountain belt. RFE (Okhotia - Amgun', Amur (east), Primorskii Krai (east); Korean Peninsula. 2n = 14 (Probatova \& Sokolovskaya 1984; Alexeev et al. 1987). $2 \mathrm{n}=2 \mathrm{x}$.

\section{Festuca rubra L., 2n = 42 (ER)}

Russia, the Far East, Primorskii Krai, Peter the Great Bay, Rechnoi Island (Amurskii Gulf), on coastal rocks, 14 Aug 2010, coll. V.A. Nechaev 11659: 26. Extremely polymorphous species, widely distributed throughout the world, with multiple CN data. In F. rubra most common is the CN $2 \mathrm{n}=42$ (6x), which was revealed throughout Russia as well, including the RFE; rarely $2 \mathrm{n}=56$ is reported. The specimen from Rechnoi Island represents the "tuft form" of Festuca rubra L. which is common on seacoastal rocks and stony slopes of marine terraces in continental part and in the islands of the Primorskii Krai (s.); its $\mathrm{CN}$ was firstly revealed. $2 \mathrm{n}=6 \mathrm{x}$.

\section{* Festuca vylzaniae (E. Alexeev) Tzvelev, 2n = 28 (ER)}

Russia, East Siberia, Republic of Buryatia, Pribaikal'skii Raion, coast of Baikal Lake, in vicinity of Turka settlement, on sands, 3 Jul 2010, coll. A.A. Gnutikov 12236: 33. Endemic of the Baikal Lake region. Sandy-steppe species. This is the first $\mathrm{CN}$ count for the species. $2 \mathrm{n}=4 \mathrm{x}$.

\section{Milium effusum L., 2n = 28 (ER)}

Russia, the Far East, Kamchatskii Krai, Kamchatka Peninsula, Verkhne-Opal'skie hot springs, $\mathrm{t}=42^{\circ} \mathrm{C}$, on the slope, in Filipendula kamtschatica community, 3 Aug 2013, coll. O.A. Chernyagina \& L. Shtreker 12457: 14. In forest edges and clearings, tall herbs communities, among shrubs. European Russia, Caucasus, West and East Siberia, RFE (up to Kamchatka in the north). Almost Holarctic. $2 \mathrm{n}=28$ (multiple CN reports from throughout Russia, and from various subregions of the RFE). First $\mathrm{CN}$ count from Kamchatka. $2 \mathrm{n}=4 \mathrm{x}$.

Poa alpigena (Blytt) Lindm. $\times$ P. arctica $\mathrm{R}$. Br., 2n $=\mathbf{4 2}(\mathrm{ER})$

Russia, the Far East, Kamchatskii Krai, Aleutskii Raion, Commander Islands, Bering Island, upper course of the Vodopadnaya River, wet forb meadow along the lakeside, 15 Aug 1999, coll. O.A. Mochalova 8085: 9. Both widely disributed Holarctic species $P$. alpigena and P. arctica are common plants in the Kamchatskii Krai, they occur in meadows, among riverside shrubs, on sands and pebbles of river valleys, on roadsides. Such hybrid is not rare, the plants have some pubescence in lower part of the lemma between veins or along veins, but at the same time they look like P. alpigena. $2 \mathrm{n}=6 \mathrm{x}$.

\section{Poa angustifolia L., 2n = 70 (AS)}

Russia, the Far East, Kamchatskii Krai, Koryakskii Natsional'nyi Okrug, Oliutorskii Raion, near Korf settlement, marine spit, middle part, grass community on sands, 17 Sep 1970, coll. N.S. Probatova \& V.P. Seledets 3100: 8. Earlier this specimen was misidentified as "Poa alpigena" in Sokolovskaya \& Probatova (1973). Dry meadows, riverside and coastal sands and pebbles, roadsides. European Russia, Caucasus, West and East Siberia, RFE (but alien on the north, in Sakhalin and in the Kurils); Eurasian. In the North Koryakia P. angustifolia is alien. $2 \mathrm{n}=56,63-64,70-72$ (from some regions of Russia, including RFE). 2n = 8x, 9x, 10x. 


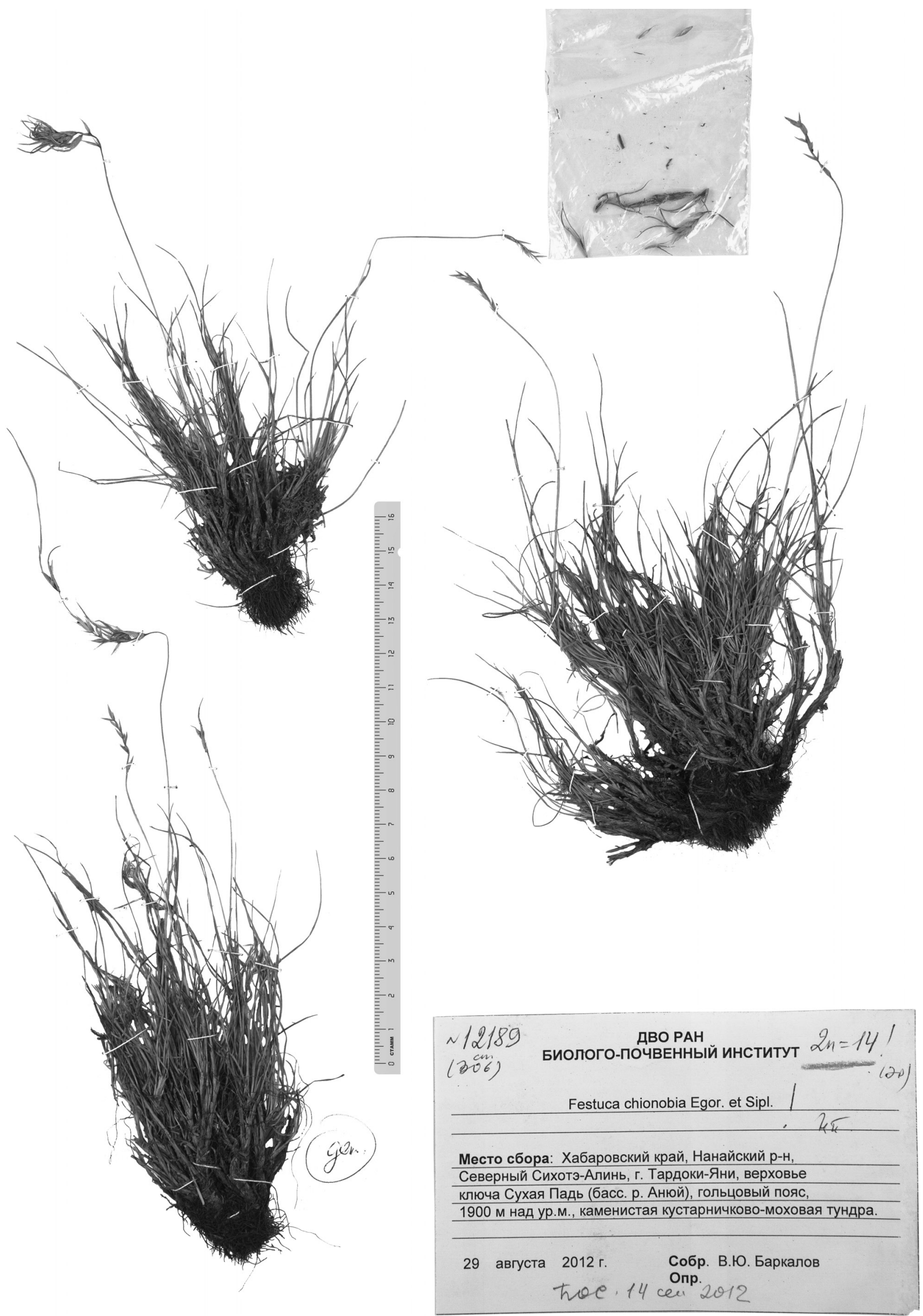

Figure 2 Specimen of pseudoviviparous Festuca chionobia with diploid CN $2 \mathrm{n}=14$, collected in study area 22 (see Fig. 1). 


\section{Poa glauca Vahl, 2n = $42(\mathrm{ER})$}

Russia, the Far East, Amurskaya Oblast', Zeyskii nature reserve, E part of Tukuringra mountain ridge, alpine zone, 15 Jul 2011, coll. T.N. Veklich 12102: 29. Mountain tundras, rocks, screes, dry pebbles in the Arctic and alpine zone of mountains. European Russia, Caucasus, West Siberia, East Siberia, RFE; Holarctic. 2n = 42, c.48, 48, 49, 50, 56, 62, 63, 70 (multiple $\mathrm{CN}$ reports from Russia and elsewhere). The $\mathrm{CN}$ of the species is studied in Amurskaya Oblast' (the Upper Amur River basin) for the first time. $2 \mathrm{n}=6 \mathrm{x}$, etc.

Poa kamczatensis Prob., 2n = 56 (ER)

Russia, the Far East, Kamchatskii Krai, Kamchatka Peninsula, near Petropavlovsk-Kamchatskii city, Bab'ya Bay, the slope of marine terrace, on rocks, 1 Aug 2014, coll. O.A. Chernyagina \& V.Yu. Neshataeva 12713: 12. On rubbly slopes of marine terraces, on rocks and screes usually of coastal hills, up to the lower mountain belt. RFE (Kamchatka - south, Okhotia (near Magadan). Endemic. 2n = 49, 56 (Sokolovskaya et al. 1985). P. kamczatensis is relative to P. almasovii Golub: most probably, these species were originated from the same (or close) species of sections Malacanthae and Stenopoa. Now they both belong to section Poastena. $2 \mathrm{n}=$ $7 \mathrm{x}, 8 \mathrm{x}$.

\section{* Poa khokhrjakovii Prob., 2n = c. 70 (AS)}

Russia, the Far East, Kamchatskii Krai, Koryakskii natsional'nyi okrug, Penzhinskii Raion, $3 \mathrm{~km} \mathrm{~S}$ of Kamenskoe settlement, rubbly slope of a hill, the upper one third, 22 Jul 1971, coll. N.S. Probatova \& V.P. Seledets 3291: 6. Dry stony slopes, in the middle and upper mountain belts. RFE (the basins of Penzhina, Omolon, Kolyma rivers). Endemic. Closely relative to $P$. malacantha Kom., but differs by narrow leaf blades, loose tufts with acuate subterranean shoots, the sheats of old leaves thin, light (and not thick, brownish), panicle branches very thin, smooth, lemmas almost glabrous between veins. First $\mathrm{CN}$ count for the species. $2 \mathrm{n}=10 \mathrm{x}$.

\section{* Poa krasnoborovii Stepanov, 2n = 42 (ER)}

Russia, East Siberia, Krasnoyarskii Krai, Ermakovskii Raion, the Us River above the mouth of the Tsap River and below the Verkhn'aya Buyba River, the Pinus and Picea forest plots on the riverside, 19 Aug 2010, coll. N.V. Stepanov 12490: 36. This species, perhaps endemic, is concerned with coniferous forests of the West Sayan Mts, where it occurs in tallgrass clearings. The species belongs to the Poa pratensis group, plants are tall, leaf blades up to $8 \mathrm{~mm}$ width, more or less rigid, ligules up to $5 \mathrm{~mm}$, panicles up to $25 \mathrm{sm}$, oblong, their branches rather long, spikelets up to $8.5 \mathrm{~mm}$. This is the first $\mathrm{CN}$ count for the species. $2 \mathrm{n}=6 \mathrm{x}$.

\section{CONCLUSION}

The 35 species presented here demonstrate the diversity of CNs: different ploidy levels, a series of basic $\mathrm{CN}$ numbers $(2 \mathrm{x}-10 \mathrm{x} ; \mathrm{x}=7,9,13)$. The diploids prevail (14 species, ca. $40 \%$ ), but only 7 species among them are primary diploids $(2 \mathrm{n}=14, \mathrm{x}=7)$, namely in Festuca, Bromopsis, Beckmannia. Also there are species with variable ploidy (sometimes expected), especially in Poa and in some Deschampsia. This phenomenon obviously indicates progressive species. The tetraploid $\mathrm{CNs}(2 \mathrm{n}=4 \mathrm{x})$ show the evolutionary optimal ploidy level for species in their taxonomic groups. The hexaploid $\mathrm{CN}(2 \mathrm{n}=6 \mathrm{x})$ may indicate the hybrid origin of the taxa. 9 species were studied caryologically for the first time, besides for 3 species the new $\mathrm{CN}$ data were obtained. Further CN studies on the Poaceae family in Russia are in process.

\section{ACKNOWLEDGEMENTS}

The study was supported by Russian Foundation for Basic Research (RFBR): grants 04-04-49750, 07-04-00610, 11-04-00240 to N.S. Probatova and grant 12-04-01586 to A.V. Verkhozina. The authors are grateful to E.G. Rudyka for chromosome countings in several species, to N.N. Tzvelev - for his help in some species identifications, also to A.V. Agafonov, L.A. Antonova, V.V. Buryi, V.V. Chepinoga, O.A. Chernyagina, A.A. Gnutikov, S.G. Kazanovsky, M.V. Krjukova, O.A. Mochalova, V.A. Nechaev, I.A. Nesterova, T.N. Veklich - for providing plant material for our study.

\section{LITERAT URE CITED}

Agapova, N.D., K.B. Arkharova, L.I. Vakhtina, E.A. Zemskova \& L.V. Tarvis 1993. Chromosome numbers in flowering plants of the flora of the USSR: Moraceae - Zygophyllaceae. Nauka, St.-Petersburg, 430 pp. (in Russian). [Агапова H.А., Архарова К.Б., Вахтина А.И., Земскова Е.А., Тарвис $\Lambda . В .1993$. Числа хромосом цветковых растений фморы СССР: семейства Moraceae-Zygophyllaceae. СПб: Наyка. 430 c.].

Alexeev, E.B., A.P. Sokolovskaya \& N.S. Probatova 1987. Taxonomy, distribution and chromosome numbers in Festuca L. (Gramineae) of the flora of USSR. 2. Section Festuca: F. djimilensis - F. lenensis. Bulleten' Moskovskogo Obshchestva Ispytatelei Prirody. Otd. biol. 92(5): 122-132 (in Russian). [А^ексеев Е.Б., Соколовская А.П., Пробатова Н.С. 1987. Таксономия, распространение и числа хромосом овсяниц (Festuca L., Gramineae) флоры CССР. 2. Секция Festuca: F. djimilensis - F. lenensis // Бюл. Моск. общ. испыт. прир. ОтА. биол. Т. 92, вып. 5. C. 122-132].

Chepinoga, V.V., A.A. Gnutikov \& I.V. Enushchenko 2010. Chromosome numbers of some plant species from the south part of the East Siberia. Botanicheskii Zhurnal 95(1): 129-130 (in Russian). [Чепинога В.В., Гнутиков А.А., Енущенко И.В. Числа хромосом некоторых виАов растений из южной части Восточной Сибири // Ботанический журнац. Т. 95, № 1. С. 129-130].

Nishikawa, T. (ed.) 2008. Chromosome atlas of flowering plants in Japan. Tokyo, 706 pp.

Petrovsky, V.V. \& P.G. Zhukova 1981. Chromosome numbers and taxonomy of some plant species of the Wrangel Island. Botanicheskii Zhurnal 66(3):380-387 (in Russian). [Петровский В.В., Жукова П.Г. 1981. Хромосомные числа и таксономия некоторых видов растений острова Врангеля // Ботанический журнал. Т. 66, № 3. C. 380-387].

Probatova, N.S. 1984. New taxa of Poaceae from the Far East of the USSR. Botanicheskii Zhurnal 69(2):251-259 (in Russian). [Пробатова Н.С. 1984. Новые таксоны сем. Роасеае с Аальнего Востока СССР // Ботанический журнал. 1984. Т. 69, № 2. С. 251-259].

Probatova, N.S. 2014. Chromosome numbers in vascular plants of the Primorskii Krai (Russian Far East). Dal'nauka, Vladi- 
vostok, 343 pp. (in Russian). [Пробатова Н.C. 2014 Хромосомные числа сосудистых растений Приморского края (АаАьний Восток России). ВАаАивосток: Аальнаука, 343 с.].

Probatova, N.S., V.Yu. Barkalov, E.G. Rudyka \& Z.V. Kozhevnikova 2009. Additions to chromosome numbers for vascular plants from Sakhalin and the Kurile Islands (1). In: Biodiversity and Biogeography of the Kuril Islands and Sakhalin (H. Takahashi \& M. Ohara, eds.), issue 3, pp. 35-47, Hokkaido University Museum, Sapporo, Japan.

Probatova, N.S., V.Yu. Barkalov, E.G. Rudyka \& S.A. Shatalova 2000. Chromosome study on vascular plants of the Kurile islands. Natural History Research 7:21-38.

Probatova, N.S., S.G. Kazanovsky, E.G. Rudyka, V.P. Seledets \& V.A. Nechaev 2012. IAPT/IOPB chromosome data 13 (K. Marhold, ed.). Taxon 61(4):899-902, E 34-42.

Probatova, N.S., A.A. Korobkov, A.A. Gnutikov, E.G. Rudyka, V.V. Kotseruba \& V.P. Seledets. 2010 IAPT/IOPB chromosome data 10 (K. Marhold, ed.). Taxon 59(6): 1934-1937, E 6-10.

Probatova, N.S., E.G. Rudyka, V.P. Seledets \& T.N. Motorykina 2014. Chromosome numbers in vascular plants from the Russian Far East: Amurskaya Oblast', Khabarovskii Krai, Primorskii Krai. Botanica Pacifica 3(2):129-134.

Probatova, N.S. \& V.P. Seledets 2008. IAPT / IOPB chromosome data 5 (K. Marhold, ed.). Taxon 57(2):555-558, E 7-16.

Probatova, N.S. \& A.P. Sokolovskaya 1978. Chromosome numbers and taxonomy of some grasses from Caucasus. Botanicheskii Zhurnal 63(8):1121-1131 (in Russian). [Пробатова Н.С., Соколовская А.П. 1978. Хромосомные числа и таксономия некоторых злаков Кавказа / / Ботанический журнац. Т. 63, № 8. С. 1121-1131].

Probatova, N.S. \& A.P. Sokolovskaya 1980. Contribution to karyotaxonomic study on Poaceae of Gornyi Altai. Botanicheskii Zhurnal 65(4):509-520 (in Russian). ППробатова Н.С., Соколовская А.П. 1980. К кариотаксономическому изучению зАаков Горного А^тая // Ботанический журнал. Т. 65, № 4. С. 509-520].

Probatova, N.S. \& A.P. Sokolovskaya 1984. Chromosome numbers in representatives of the families Butomaceae, Papaveraceae, Poaceae from the Far East of the USSR. Botanicheskii Zhurnal 69(3):410-412 (in Russian). [Пробатова Н.С., Соколовская А.П. 1984. Числа хромосом представителей семейств Butomaceae, Papaveraceae, Poaceae с Аальнего Востока СССР // Ботанический журнал. T. 69, № 3. C. 410-412].

Probatova, N.S., A.P. Sokolovskaya \& E.G. Rudyka 1991. Chromosome numbers of some vascular plant species from the Far East and other regions of the USSR. Botanicheskii Zhurnal 76(8):1174-1178 (in Russian). [Пробатова Н.С., Соколовская А.П., Рудыка Э.Г. 1991. Числа хро-

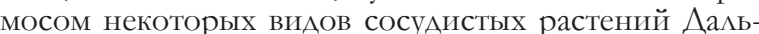
него Востока и Аругих регионов СССР / / Ботанический журнаА. Т. 76, № 8. С. 1174-1178].

Prokudin, Yu.N., A.G. Vovk, O.A. Petrova, E.D. Ermolenko \& Yu.V. Vernichenko 1977. Poaceae of Ukraine. (Survey of anatomy, morphology, karyosystematics, ecology and phytocoenology). Kiev, 518 pp. (in Russian). [Прокудин Ю.Н., Вовк А.Г., Петрова О.А., Ермоленко Е.А., Верниченко Ю.В. 1977. ЗАаки Украины. (Анатомо-морфологический, кариосистематический и эколого-фитоценотический об̆зор). Киев. 518 с.].

Sarapul'tsev, I.E. 2001. The phenomenon of pseudoviviparity in alpine and arctomontane grasses (Deschampsia Beauv., Festuca L. and Poa L.). Russian Journal of Ecology 32(3):170-178.
Sokolovskaya, A.P. 1970. Karyological study on the flora of the Ussa River basin (Komi ASSR). Vestnik Leningradskogo Universiteta, Biol. 2(9):106-114 (in Russian). [Сокомовская А.П. 1970. Кариологическое исследование флоры бассейна р. Усы (Коми АССР) // Вестник Аенингр. унив., Биом. Вып. 2, № 9. С. 106-114].

Sokolovskaya, A.P. \& N.S. Probatova 1973. Karyotaxonomic study on the Far East species of Poa L. II. Botanicheskii Zhurnal 58 (1): 89-96 (in Russian). [Соколовская А.П., Пробатова Н.С. 1973. Кариосистематическое исследование Аальневосточных видов Poa L. II // Ботанический журнал. Т. 58, № 1. С. 89-96].

Sokolovskaya, A.P. \& N.S. Probatova 1975. Chromosome numbers of some grasses (Poaceae) of the flora of USSR. Botanicheskii Zhurnal 60(5):667-678 (in Russian). [Соколовская А.П., Пробатова Н.С. 1975. Хромосомные числа некоторых зцаков (Росеае) флоры СССР // Ботанический журнал. Т. 60, № 5. С. 667-678].

Sokolovskaya, A.P. \& N.S. Probatova 1978. Chromosome numbers of some grasses (Poaceae) of the flora of USSR. II. Botanicheskii Zhurnal 63(9):1247-1257 (in Russian). [Соколовская А.П., Пробатова Н.С. 1978. Ботанический журнал. Т. 63, № 9. С. 1247-1257].

Sokolovskaya, A.P. \& N.S. Probatova 1979. Chromosome numbers of some grasses (Poaceae) of the flora of USSR. III. Botanicheskii Zhurnal 64(9):1245-1258 (in Russian). [Соколовская А.П., Пробатова Н.С. 1979. Ботанический журнал. Т. 64, № 9. С. 1245-1258].

Sokolovskaya, A.P., N.S. Probatova \& E.G. Rudyka 1985. Chromosome numbers in species of the families Asteraceae, Poaceae, Rosaceae from Primorskii Krai, Kamchatka and Sakhalin. Botanicheskii Zhurnal 70(1):126-128 (in Russian). [Соколовская А.П., Пробатова Н.С., Рудыка Э.Г. 1985. Числа хромосом видов семейств Asteraceae, Poaceae, Rosaceae из Приморского края, Камчатки и Сахалина // Ботанический журнал. Т. 70, № 1. С. 126-128].

Tzvelev, N.N. 2013. Notes on some genera of the Family Poaceae. Novitates systematicae plantarum vascularium 44:26-38 (In Russian). Цвелёв Н.Н. 2013. Заметки о некоторых родах семейства зАаков (Роасеае) // Новости систематики высших растений. СПб. Т. 44. С. 26-38].

Tzvelev, N.N. \& N.S. Probatova 2010 a. New taxa of grasses (Poaceae) of Russia. Botanicheskii Zhurnal 95(6):857-869 (in Russian). Цвелёв Н.Н., Пробатова Н.С. 2010. Новые таксоны зАаков (Роaceae) России // Ботанический журнал. Т. 95, № 6. С. 857-869].

Tzvelev, N.N. \& N.S. Probatova 2010 b. The genera Elymus L., Elytrigia Desv., Agropyron Gaertn., Psathyrostachys Nevski and Leymus Hochst. (Poaceae: Triticeae) in the flora of Russia. Komarovskie Chtenya 57:5-102 (in Russian). Цвелев Н.Н., Пробатова Н.C. 2010. Роды Elymus L., Elytrigia Desv., Agropyron Gaertn., Psathyrostachys Nevski и Leymus Hochst. (Poaceae: Triticeae) во флоре России // Комаровские чтения. Вып. 57. С. 5-102.].

Tzvelev, N.N. \& N.S. Probatova 2012. The survey of genera Deschampsia, Agrostis, Calamagrostis (Poaceae - Poeae) and the system of Poaceae in the flora of Russia. Komarovskie Chtenya (Vladivostok) 59:7-75 (in Russian). Щвелёв Н.H., Проб̆атова Н.С. 2012. Обзор родов Deschampsia, Agrostis, Calamagrostis (Poaceae - Poeae) и система зцаков фцоры России // Комаровские чтения (ВАадивосток). Вып. 59. C. 7-75].

Zhukova, P.G., V.V. Kotseruba \& V.V. Pertovsky 2009. Chromosome numbers in plant species from the North Eurasia. Botanicheskii Zhurnal 94(12):1855-1867 (in Russian). [Жукова П.Г., Коцеруба В.В., Петровский В.В. 2009. Числа хромосом вилов растений Севера Евразии // Ботанический журнал. Т. 94, № 12. С. 1855-1867]. 
Zhukova, P.G. \& V.V. Petrovsky 1975. Chromosome numbers in some plant species from the West Chukotka. Botanicheskii Zhurnal 60(3):395-401 (in Russian). [Жукова П.Г., Петровский В.В. 1975. Хромосомные числа некоторых видов растений Западной Чукотки // Ботанический журнал. Т. 60, № 3. С. 395-401].

Zhukova, P.G. \& V.V. Petrovsky 1976. Chromosome numbers in some plant species from West Chukotka. II. Botanicheskii Zhurnal 61(7):963-969 (in Russian). [Жукова П.Г., Петровский В.В. 1976. Хромосомные числа некоторых видов растений ЗапаАной Чукотки. II // Ботанический журнац. 1976. Т. 61, № 7. С. 963-969].

Zhukova, P.G. \& V.V. Petrovsky 1980. Chromosome numbers and taxonomy of some species of the Anyui Mts. Botanicheskii Zhurnal 65(5):651-659 (in Russian). [Жукова П.Г., Петровский В.В. 1980. Хромосомные числа и таксономия некоторых видов растений Анюйского нагорья // Ботанический журнал. Т. 65, № 5. С. 651-658].

Zhukova, P.G., V.V. Petrovsky \& T.V. Plieva 1973. Chromosome numbers and taxonomy of some plant species from Siberia and the Far East. Botanicheskii Zhurnal 58(9):13311342 (in Russian). [Жукова П.Г., Петровский В.В., Плиева Т.В. 1973. Хромосомные числа и таксономия не- которых видов растений Сибири и Аальнего Востока // Ботанический журнал. Т. 58, № 9. С. 1331-1342].

Zhukova, P.G. \& A.D. Tikhonova 1973. Chromosome numbers in some plant species from Chukotka. II. Botanicheskit Zhurnal 58(3):395-402 (in Russian). [Жукова П.Г., Тихонова А.А. 1973. Хромосомные числа некоторых видов растений Чукотки. II // Ботанический журнал. Т. 58, № 3. C. 395-402].

Yurtzev, B.A. \& P.G. Zhukova 1978. Cytotaxonomical survey of Monocots in the east of Chukotka Peninsula. Botanicheskii Zhurnal 63(8):1132-1144 (in Russian). [Юpцев Б.А., Жукова П.Г. 1978. Цитотаксономический обзор однодОАьных востока Чукотского полуострова // Ботанический журнац. Т. 63, № 8. С. 1132-1144].

Yurtzev, B.A. \& P.G. Zhukova 1982. Chromosome numbers in some plants from the north-east of Yakutia (the basin of middle course of the Indigirka River). Botanicheskii Zhurnal 67(6):778-787 (in Russian). [Юрцев Б.А., Жукова П.Г. 1982. Хромосомные числа некоторых растений северо-восточной Якутии (бассейн среднего течения реки Индигирки) // Ботанический журнац. T. 67, № 6. С. 778-787]. 